\title{
IMPLEMENTASI PROSES PEMBELAJARAN PASCA SURAT EDARAN NOMER 15 TAHUN 2020 TENTANG PEDOMAN PEMBELAJARAN DARI RUMAH DALAM MASA DARURAT PANDEMI COVID-19
}

\author{
Husnan ${ }^{1}$, Ahmad Helwani ${ }^{2}$, Nurjannah ${ }^{3}$ \\ 1,2,3Program Studi Bahasa Arab, Universitas Muhammadiyah Mataram, Indonesia \\ $\underline{\text { Husnanhanan4780@gmail.com }}{ }^{1}$, ahelwani1407@gmail.com ${ }^{2}$, arkounfukayna@gmail.com $^{3}$
}

\begin{tabular}{l}
\hline INFO ARTIKEL \\
\hline Riwayat Artikel: \\
Diterima: 02-06-2021 \\
Disetujui: $30-10-2021$ \\
\end{tabular}

\section{Kata Kunci:}

Proses Pembelajaran Pasca, Surat Edaran Nomer 15-2020, Pedoman Pembelajaran,

Masa Darurat Pandemi Covid-19

\section{Keywords:}

Post-Learning Process, Circular Letter Number 15-2020, Learning Guidelines,

Covid-19 Pandemic Emergency Period

\begin{abstract}
ABSTRAK
Abstrak:
Proses belajar di masa pandemi covid -19 bukan alasan untuk tidak belajar meski kegiatan berkumpul dilarang oleh pemerintah. Untuk menghentikan mata rantai penularan virus ini, setiap orang harus menjaga jarak dengan orang lain. Dengan demikian proses pembelajaran di sekolah ditiadakan demi menjaga keamanan bersama. Selanjutnya, pemerintah kemudian mengeluarkan surat edaran tentang tata cara belajar mengajar untuk menghindari keramaian dan tatap muka di dalam kelas. Tetap berada dirumah merupakan satu-satunya solusi pada saat pandemi covid 19, oleh karena itu proses pembelajaran tetap dilaksanakan walaupun dari rumah atau tempat tinggal siswa. Prinsip Pelaksanaan Belajar Dari Rumah (BDR) dilaksanakan sesuai dengan prinsip-prinsip yang tertuang dalam Surat Edaran Menteri Pendidikan dan KebudayaanNomor 4 Tahun 2020tentangPelaksanaan Kebijakan Pendidikan dalam Masa Darurat Penyebaran Corona Virus Disease (COVID 19) Pembelajaran jarak jauh atau learning from home menjadi pilihan dengan memanfaatkan teknologi digital sebagai media pembelajaran. Metode pembelajaran di dalam jaringan atau di luar jaringan digunakan oleh guru. Belajar dari rumah (BDR) adalah proses pembelajaran yang dilakukan oleh guru dan siswa dengan menggunakan internet karena guru dan siswa tidak berada dalam satu tempat. Tujuan Penelitian ini adalah untuk mengetahui proses pembelajaran pasca surat edaran nomor 15 tahun 2020 tentang pedoman pembelajaran dari rumah dalam masa darurat covid 19.
\end{abstract}

\begin{abstract}
:
The learning process during the covid -19 pandemic is not an excuse not to study even though gathering is prohibited by the government. To stop the chain of transmission of this virus, everyone must keep their distance from others. Thus the learning process at school is abolished in order to maintain mutual safety. Furthermore, the government then issued a circular on teaching and learning procedures to avoid crowds and face to face in classrooms. Distance learning or learning from home is an option by utilizing digital technology as a learning medium. In-network or offnetwork learning methods are used by teachers. Learning from home (BDR) is a learning process carried out by teachers and students using the internet because teachers and students are not in one place. This study uses a qualitative approach in the process of collecting data from the field. The data collection techniques were carried out by means of observation, interviews and documentation. After this research was carried out at Madrasah Aliah Attahzib, the researchers found that the learning process carried out in this Madrasa after the issuance of the circular letter of the ministry of education and culture number 15 of 2020 regarding the learning process from home was divided into three phases.
\end{abstract}

\section{A. LATAR BELAKANG}

SXejak pandemi covid -19 mewabah sejak satu tahun yang lalu, seluruh sektor kehidupan mengalami perubahan. Indonesia salah satu negara yang sangat terdampak dengan pandemi ini, sejak resmi di umumkan pada tanggal 2 maret 2020 oleh pemerintah bahwa jumlah pasien yang terinfeksi oleh covid-19 semakin meningkat. Data terbaru yang dikeluarkan oleh tim gugus nasaional per 12 Januari 2021 total masyarakat yang terpapar 864.765 orang.
Akibat dari mewaVzbahanya covid -19 , semua sektor merasakan dampak yang luar biasa seperti pariwisata, pertanian dan tak terkecuali pendidikan. Keputusan pemerintah untuk meliburkan sekolah atau memindahkan proses pembelajaran dari sekolah ke rumah membuat semua pihak terkejut dan kelimpungan. Pihak sekolah menjadi kebingungan untuk melakasanakan proses belajar mengajar, karena belajar tatap muka tidak diperbolehkan. Peralihan bentuk belajar dari manual menuju digital belum sepenuhnya bisa dilaksanakan. Faktor penguasaan 
teknologi, minimalnya sarana dan prasarana, jaringan internet dan biaya tinggi menjadi sebab tidak maksimalnya pembelajaran dengan proseses dalam jaringan (daring).

Sebagian sekolah yang memiliki sumber daya yang memadai tentu tidak akan mengalami banyak kesulitan dalam mengimplementasikan pembelajaran dari rumah. Akan tetapi untuk sebagaian kalangan dan sebagaian wilayah yang tidak didukung oleh sumberdaya yang memadai, maka tidak akan mampu berbuat banyak dalam melaksanakan proses pembelajaran.

Dengan adanya edaran dari kementrian dan kebudayaan nomer 15 tahun 2020 tentang pedoman pembelajaran dari rumah dalam masa darurat pandemi covid -19, maka pembelajaran sudah tidak diperbolehkan dilaksanakan dalam bentuk tatap muka disekolah.

Prinsip Pelaksanaan Belajar Dari Rumah (BDR) dilaksanakan sesuai dengan prinsip-prinsip yang tertuang dalam Surat Edaran Menteri Pendidikan dan KebudayaanNomor 4 Tahun 2020tentangPelaksanaan Kebijakan Pendidikan dalam Masa Darurat Penyebaran Corona Virus Disease (COVID 19), yaitu: Pertama, keselamatan dan kesehatan lahir batin peserta didik, pendidik, kepala satuan pendidikan dan seluruh warga satuan pendidikan menjadi pertimbangan utama dalam pelaksanaan BDR. Kedua, kegiatan BDR dilaksanakan untuk memberikan pengalaman belajar yang bermakna bagi peserta didik, tanpa terbebani tuntutan menuntaskan seluruh capaian kurikulum. Ketiga, BDR dapat difokuskan pada pendidikan kecakapan hidup, antara lain mengenai pandemi COVID-19, Keempat, Materi pembelajaran bersifat inklusif sesuai dengan usia dan jenjang pendidikan, konteks budaya, karakter dan jenis kekhususan peserta didik, Kelima, Aktivitas dan penugasan selama BDR dapat bervariasi antar daerah, satuan pendidikan dan Peserta Didik sesuai minat dan kondisi masing-masing, termasuk mempertimbangkan kesenjangan akses terhadap fasilitas BDR, Keenam, Hasil belajar peserta didik selama BDR diberi umpan balik yang bersifat kualitatif dan berguna dari gurutanpa diharuskan memberi skor/nilai kuantitatif, danKetujuh, Mengedepankan pola interaksi dan komunikasi yang positif antara guru dengan orang tua/wali.

Dalam surat edaran ini disebutkan bahwa tujuan dari pelaksanaan Belajar Dari Rumah (BDR) adalah memastikan pemenuhan hak peserta didik untuk mendapatkan layanan pendidikan selama darurat Covid-19, melindungi warga satuan pendidikan dari dampak buruk Covid-19, mencegah penyebaran dan penularan Covid-19 di satuan pendidikan dan memastikan pemenuhan dukungan psikososial bagi pendidik, peserta didik, dan orang tua.

Belajar Dari Rumah dilaksanakan dengan pembelajaran jarak jauh, menggunakan dua pendekatan yaitu; pembelajaran jarak jauh dalam jaringan (daring) dan pembelajaran jarak jauh luarjaringan (luring) dalam pelaksanaan PJJ. Satuan pendidikan dapat memilih pendekatan (daring atau luring atau kombinasi keduanya) sesuai dengan ketersediaan dan kesiapan sarana dan prasarana. Mediadan Sumber Belajar Pembelajaran Jarak Jauh Daring Pembelajaran di rumah secara daring dapat menggunakan gawai (gadget) maupun laptop melalui beberapa portal dan aplikasi pembelajaran daring.

Dalam kenyataanya proses pembelajaran jarak jauh yang sudah ditentukan tata caranya oleh pemerintah dalam hal ini kementrian pendidikan dan kebudayaan belum seutuhnya diterapkan oleh semua sekolah. Pihak sekolah melakukan berbagai macam kreasi proses pembelajaran dalam rangka menafsirkan surat edaran kementrian tersebut. Hal itu, tentunya dilatar belakangi oleh berbagai macam kendala dan problem yang dihadapi oleh pihak sekolah.

Terdapat beberapa sekolah yang masih menggunakan proses pembelajaran tatap muka tapi tidak disekolah, selain itu ada juga yang melakukan pembelajaran di sekolah tapi dengan tempo yang di atur sedemikian rupa. Inilah ragam rupa dari proses pembelajaran selama covid -19 bahkan sampai hari ini di sekolah. Apakah ini tafsir lain dari surat edaran kementrian pendidikan dan kebudayaan tentang belajar dari rumah atau ada faktor-faktor lain yang menyebabkan proses belajar harus dilakukan sesuai dengan kondisi sekolah masing-masing. Melihat fenomena tersebut maka perlu dicari tahu apa yang melatar belakangi pihak sekolah dalam melaksanakan proses belajar dan bagaimana implementasinya.

\section{B. METODE PENELITIAN}

\section{A. Pendekatan Penelitian}

Dalam penelitian ini peneliti menggunakan penelitian kualitatif karena data dan informasi yang peneliti kumpulkan lebih banyak bersifat keterangan-keterangan atau penjelasan yang bukan berbentuk angka. Penelitian kualitatif adalah penelitian yang digunakan untuk meneliti pada kondisi objek yang alamiah.

Selain itu, penggunaan pendekatan kualitatif ini disebabkan karena peneliti ingin mengetahui gambaran atau deskripsi yang jelas tentang Implementasi Proses Pembelajaran Pasca Surat Edaran Nomer 15 Tahun 2020 Tentang Pedoman Pembelajaran Dari Rumah Dalam Masa Darurat 
Pandemi Covid - 19 di Madrasah Aliah Attahzib Kekait Kecamatan Gunungsari.

\section{B. Sumber Data}

Sumber data adalah dari mana data penelitian itu akan diperoleh dan dikumpulkan. Kualitas data ditentukan oleh kualitas alat pengambil data atau alat pengukurnya. Kalau alat pengambil datanya cukup reliabel dan valid, maka datanya juga akan cukup reliabel dan valid. Data terbagi menjadi dua bagian yaitu data primer, yaitu data yang langsung dikumpulkan peneliti dari sumber pertama. Disamping data primer diperoleh oleh peneliti, data sekunder biasanya telah tersusun dalam bentuk dokumen. Berkaitan dengan penelitian ini maka sebagai sumber data penelitian adalah :

a. Kepala sekolah Madrsah Aliah Attahzib Kekait Kecamatan Gunungsari

b. Guru Madrsah Aliah Attahzib Kekait Kecamatan Gunungsari

c. Siswa Madrsah Aliah Attahzib Kekait Kecamatan Gunungsari

\section{TeknikPengumpulan Data}

Untuk mendapatkan data sesuai dengan yang diinginkan dalam penelitian kualitatif, maka proses pengumpulan data lazimnya menggunakan observasi dan wawancara, juga tidak diabaikan sumber-sumber non manusia, seperti dokumen dan rekaman/catatan yang tersedia. Dibawah ini akan diuraikan teknik/metode penelitian sebagai cara yang dapat ditempuh untuk mengumpulkan data sebagai berikut.

\section{Observasi}

Metode observasi adalah teknik pengumpulan data yang dilakukan melalui suatu pengamatan, dengan disertai pencatatan-pencatatan terhadap keadaan atau perilaku objek sasaran. Orang yang melakukan observasi disebut pengobservasi (observer) dan pihak yang diobservasi disebut terobservasi (observee). Dalam penelitian ini, peneliti menggunakan observasi non partisipatif, yaitu peneliti hanya sebagai pengamat atau observator, peneliti tidak ikut mengambil bagian dan cukup hanya dengan mengamati.

\section{Wawancara}

Wawancara adalah teknik pengumpulan data melalui proses tanya jawab lisan yang berlangsung satu arah, artinya pertanyaan datang dari pihak yang mewancarai dan jawaban diberikan oleh yang diwawancara. Melalui metode wawancara ini, peneliti mencoba untuk menggali data yang berkaitan dengan isi penelitian.

Dalam peneliti ini akan digunakan jenis wawancara tidak terstruktur karena jenis wawancara ini sangat memudahkan peneliti, wawancara tidak terstruktur ini adalah wawancara bebas, sehingga peneliti bisa lebih leluasa untuk mendapatkan informasi yang dibutuhkan secara langsung dari para narasumber yang terkait dengan penelitian yang dilakukan oleh peneliti saat ini. Dalam hal ini responden yang dibutuhkan adalah:

a. Kepala sekolah Madrsah Aliah Attahzib Kekait Kecamatan Gunungsari

b. Guru Madrasah Aliah Attahzib Kekait Kecamatan Gunungsari

c. Siswa Madrasah Aliah Attahzib Kekait Kecamatan Gunungsari

\section{Dokumentasi}

Dokumentasi ialah teknik pengumpulan data dengan mempelajari catatan-catatan mengenai data pribadi responden. Dokumentasi ditujukan untuk memperoleh data langsung dari tempat penelitian, meliputi buku-buku yang relevan, peraturan-peraturan, laporan kegiatan, foto-foto, film documenter, data yang relevan dengan penelitian. Dokumentasi digunakan sebagai bukti pelaksanaan pembelajaran dalam penelitian.

\section{TeknikAnalisis Data}

Melakukan analisis berarti melakukan kajian untuk memahami struktur suatu fenomenafenomena yang berlaku di lapangan. Analisis dilaksanakan dengan melakukan telaah terhadap fenomena atau peristiwa secara keseluruhan, maupun terhadap bagian-bagian yang membentuk fenomena-fenomena tersebut serta hubungan keterkaitannya.

Dalam menganalisis data peneliti menggunakan metode induktif untuk menarik kesimpulan terhadap hal-hal peristiwa dari data yang telah dikumpulkan melalui metode observasi, wawancara, dan dokumentasi yang telah digeneralisasikan. Analisis induktif ini lebih khusus peneliti gunakan untuk menganalisa data hasil wawancara guna mendapatkan suatu kesimpulan yang utama dari beberapa hasil wawancara yang didapatkan di lapangan.

Jadi, dalam hal ini peneliti menyimpulkan bahwa analisis data merupakan salah satu langkah yang sangat penting dalam penelitian untuk memperoleh generalisasi atau kesimpulan tentang masalah yang diteliti sehingga nantinya kebenaran dan validitas datanya dapat dipertanggung jawabkan. 


\section{HASIL DAN PEMBAHASAN}

1. Implementasi Proses Pembelajaran Pasca Surat Edaran Nomer 15 Tahun 2020 Tentang Pedoman Pembelajaran Dari Rumah Dalam Masa Darurat Pandemi Covid - 19 di Madrasah Aliah Attahzib Kekait Kecamatan Gunungsari

Pandemi covid 19 telah mengubah seluruh tatanan kehidupan manusia di seluruh dunia. Seluruh sektor kehidupan mengalami perubahan dari cara yang biasa menjadi luar biasa, dari yang manual menjadi digital. Begitu bahayanya virus corona, maka untuk menyelamatkan jiwa manusia maka seluruh dunia menerapkan tiga kebiasan baru yang harus dilakukan yaitu; menjaga jarak memakai masker dan mencuci tangan.

Seluruh kegiatan masyarakat harus menerapkan protokol kesehatan sebagai syarat menyelenggarakan kegiatan, serta ditambah dengan pembatasan jumlah. Hal tersebut berlaku pada seluruh kegiatan masyarakat baik negri maupun suwasta, pribadi maupun kelompok. Semua itu bertujuan untuk memutus rantai penyebaran virus corona.

Dunia pendidikan pada awal penyebaran virus corona cukup membuat bingung para pemangku kebijakan. Berbagai kebijakan pun dikeluarkan mulai dari meliburkan sekolah, bergantian masuk sekolah sampai dengan belajar jauh dari sekolah. Tentu hal tersebut memiliki dasar yang kuat yaitu demi keselamatan bersama dan tetap terpenuhinya hak-hak belajar para siswa.

Ditengah wabah virus corona yang masih mewabah bahkan samapai hari virus tersebit telah bermutasi semakin ganas, pemerintah dalam hal ini mentri pendidikan dan kebudayaan mengeluarkan Surat Edaran Nomer 15 Tahun 2020 Tentang Pedoman Pembelajaran Dari Rumah Dalam Masa Darurat Pandemi Covid - 19.

Pasca surat edaran tersebut, maka seluruh sekolah di Indonesia tidak diperkenankan untuk melaksanakan proses belajar tatap muka di sekolah. Proses belajar menekankan tidak boleh terjadi kerumunan di satu tempat. Untuk menghindari kerumunan maka pendekatan belajar dibuat menjadi belajar dari rumah (BDR). Adapun tujuan dikeluarkannya surat edaran terkait dengan proses belajar dari rumah adalah untuk:

1. Memastikan pemenuhan hak peserta didik untuk mendapatkan layanan pendidikan selama darurat COVID-19;

2. Melindungi warga satuan pendidikan dari dampak buruk COVID-19;

3. Mencegah penyebaran dan penularan COVID19 di satuan pendidikan dan
4. Memastikan pemenuhan dukungan psikososial bagi pendidik, peserta didik dan orang tua/wali.

Perlindungan dan pemenuhan hak atas peserta didik menjadi prioritas utama dari surat edaran tersebut. Untuk memenuhi hal tersebut maka dimulailah proses pembelajaran dengan situasi baru dimana antara guru dan peserta didik tidak bertemu secara langsung. Pembelajaran jarak jauh ini mengandalkan teknologi sebagai media utama dan internet sebagai penggeraknya. Materi dan informasi dari guru semuanya disampaikan berbagai macam aplikasi, seperti whatsapp, google classrum, zoom meeting atau E learing lainnya.

1. Fase Pembelajaran dengan E-Learning di Madrasah Aliah Attahzib

Pasca surat edaran kementrian Pendidikan dan Kebudayaan dikeluarkan oleh pemerintah, maka sejak itu semua lembaga pendidikan dilarang melakasanakan belajar tatap muka. Proses pembelajaran diatur sangat ketat demi menghindari terjadinya kerumunan di satu tempat. Pembelajaran dari rumah adalah pendekatan yang ditekankan oleh pemerintah untuk dilaksanakan dengan berbagai model dan teknik pembelajaran diserahkan kepada sekolah bersangkutan. Sesungguhnya belajar online memiliki banyak manfaat bila dapat dilaksanakan dengan baik. Diantara manfaat yang didapat dari proses belajar online ini adalah:

1. Efesiensi waktu pembelajaran dan akses sumber belajar yang tak terbatas.

2. Membangun komunikasi yang efesien antara guru dan murid.

3. Dapat melakukan diskusi antar siswa tampa harus ada guru

4. Memudahkan intraksi antra siswa, guru dan orang tua

5. Guru dapat dengan mudah memberikan materi berupa gambar atau video.

Dari berbagai manfaat belajar online diatas secara nyata belum dapat dirasakan oleh guru dan para siswa di Madrasah Aliah Attahzib Kekait. Secara umum belajar dengan cara online ini memang memiliki tingkat perbedaan kesulitan antara satu daerah dengan daerah lain, satu sekolah dengan sekolah lainnya. Begitu juga dengan Madrasah Aliah Attahzib, berbagai faktor dapat menjadi penyebab semua itu, bisa jadi sumber daya manusianya juga peralatan-peralatan yang tersedia.

Madrasah Aliah attahzib Kekait sebagai salah satu Madrasah yang ada di desa kekait dengan jumlah peserta didik 182 orang. Perubahan model belajar dari model langsung (offline) menjadi tidak 
langsung (online) menyisakan permasalahan tersendiri bagi pihak madrasah. Diantara pesrmasalahan yang dihadapi adalah keterbatasan alat serta dana untuk melaksanakan pembelajaran dengan menggunakan cara Daring (dalam Jaringan) serta tidak didukung oleh sumber daya yang baik.

Terbatasnya alat seperti leptop atau komputer yang tersambung langsung dengan internet menjadi kendala dalam proses pembelajaran. Melayani siswa dengan jumlah besar pada satu waktu tentu sangat sulit untuk dilakukan. Apalagi alat-alat yang dimiliki masih digunakan bersama dengan Madrasah Tsanawiah Attahzib. Selain itu kebijakan tentang aplikasi yang akan digunakan untuk belajar online masih bermacam-macam. Madrasah Aliah attahzib yang bernaung dibawah kementrian Agama pada saat itu menggunakan aplikasi E-learning. E-Learing adalah sebuah aplikasi yang dirancang khusus untuk pembelajaran dengan berbagai kontain satuan pembelajaran seperti materi, absensi dan evaluasi pembelajaran.

Aplikasi ini dapat diinstal di HP. Sehingga pada saat itu pembelajaran di Madrasah Aliah Attahzib menggunakan gitget sebagai media utama dalam penyampaian materi oleh guru. Sejak menggunakan aplikasi ini proses pembelajaran tidak bisa bejalan dengan baik. Ada beberapa sebab hal itu terjadi. Pertama, proses pembelajaran dengan cara online membutuhkan HP dan Pulsa sebagai penghubung. Pada kenyataannya proses pembelajaran pada fase ini ketika jam belajar sudah dimulai para siswa banyak yang belum tersambung atau bergabung dalam proses pembelajaran. Kedua, dengan belajar online susungguhnya akan memberi banyak kemudahan, akan tetapi proses belajar dengan online sangat mengandalkan guru dan proses intraksi antara guru dan siswa sangat minim. Ketiga, dengan belajar online para siswa dengan bebas dapat mengakses berbagai sumber belajar dari internet, namun permasalahannya adalah tidak terjadi proses internalisasi pengetahuan oleh para siswa karena mereka terkesan hanya sekedar menyelesaikan tugas saja. Keempat, belajar dengan cara online dirasakan sulit ketika guru ingin memberikan penjelasan tentang sebuah materi yang membutuhkan pemahaman, demikian pula pada materi yang bersifat aplikatif.

Situasi ini tentunya tidak baik untuk sekolah dan peserta didik. Sekolah sebagai organisasi pendidikan memiliki admistrasinya sendiri. Segala kegiatan sekolah sudah tertuang di dalam kurikulumnya, sehingga target capaian dari kurikulum itu harus dapat dicapai. Ketuntasan dalam belajar dan ketuntasan dalam penyampaian materi ajar memiliki batas waktu tertentu sehingga semua elemen belajar akan seirama ketuntasannya dengan proses ujian sekolah.

Melihat situasi yang tidak berjalan baik ketika proses pembelajaran dengan E-learning dilaksanakan di Madrasah Aliah attahzib, maka kepala sekolah membuat kebijakan berani dengan tidak menggunakan proses pembelajaran online dengan aplikasi E-Learning dan tidak bisa juga semua model belajar jarak jauh.

\section{Fase Pembelajaran Jadwal Terbatas Di Madrasah Aliah Attahzib}

Setelah tidak menggunakan model pembelajaran online dan ditambah lagi dengan turun naiknya situasa covid -19 yang tidak menentu. Kepala Madrasah Aliah Attahzib mencoba dan memberanikan diri untuk meaksanakan pembelajaran dengan tatap muka tapi terbatas.

Pada fase ini jadwal pembelajaran tatap muka diatur dengan ketat dengan memperhatikan protokol kesehatan. Para peserta didik melakukan proses pembelajaran di sekolah. Jadwal pembelajaran diatur dengan cara bergantian (shipt). Setiap kelas diberikan waktu selama dua jam untuk belajar di kelas. Setelah dua jam selesai maka akan diganti dengan kelas lainnya. Proses ini dilakukan untuk tahap-tahap awal sebagai uji coba selama satu bulan. Setelah proses belajar model terjadwal ini berjalan dan tidak menimbulkan akibat negatif dari proses ini, waktu belajar ditingkatkan kembali menjadi empat jam setiap hari. Begitu juga ketika situasinya berjalan baik waktu belajar ditingkatkan menjadi situasi normal.

Madrasah Aliah attahzib adalah satu satunya sekolah yang melakukan proses belajar tatap muka langsung di desa Kekait diantara sekolahsekolah lainnya. Para petugas covid -19 bersama Babinkabtimas sebenernya telah beberapa kali memberikan teguran kepada kepala sekolah atas proses pembelajaran tatap muka ini, agar diberhentikan karena tidak sesuai dengan edaran dari pemerintah tentang pembelajaran di masa pandemi. Dengan berbagai alasan dan argumen yang diberikan oleh kepala sekolah serta dukungan yang diberikan oleh ketua yayasan dan seluruh wali maka proses pembelajaran tetap berlanjut dengan tatap muka.

\section{Fase Pembelajaran Tatap muka di Madrasah Aliah Atahzib}

Setelah proses pembelajaran berjadwal berjalan baik serta situasi tetap terkendali, bahkan tidak ada teguran dari pihak dinas pendidikan (kemenag) atas proses pembelajaran tatap muka di 
Madrasah Aliah Attahzib Kekait. Maka selanjuatnya kepala sekolah memutuskan proses pembelajaran dilakukan sebagai mana layaknya situasi normal. Sebelum keputusan bahwa proses pembelajaran dilakukan seperti biasa, kepala sekolah mendapat dukungan kuat dari ketua yayasan dan para wali murid. Para wali murid sesungguhnya sudah mulai jenuh dengan situasi anak-anak mereka dengan proses belajar online yang menurut mereka tidak efektif. Oleh karena itu para wali murid sepakat untuk membuat surat pernyataan bermatrai sebagai bentuk dukungan dlakukannya belajar sebagai mana normalnya.

Proses pembelajaran tatap muka dilakaukan sesuai standar kesehatan covid -19. Terlihat memang di beberapa tempat di area sekolah kran-kran untuk membasuh tangan. Selain itu para peserta didik juga menggunakan masker. Tempat duduk juga diataur berjarak. Pembelajaran dikelas dengan tatap muka ini berjalan baik untuk permulaannya sesuai dengan standar kesehatan yang ditekankan oleh pemerintah. Namun pada tahap-tahap selanjutnya penulis melihat prosedur kesehatan tidak terlalu diperdulikan. Terlihat para siswa berkumpul-kumpul tidak jaga jarak tidak juga pake masker. Namun yang menjadi penyemangat pihak sekolah secara khusus dan warga di desa kekait adalah setelah satu tahun lebih menyebarnya virus corona belum ada satupun dari mereka yang terjangkit atau terpapar virus korona.

\section{Sub Judul}

\section{A. Komponen sistem dalam Pembelajaran}

Pembelajaran adalah kegiatan komunikasi antara guru dengan para siswa di tempat tertentu tentang materi-materi tertentu. Proses komunikasi ini bertujuan untuk memberikan perubahan yang berkelanjutan pada diri para siswa. Dari urain diatas maka proses belajar mengajar yang baik itu memang mensyaratkan beberpa komponen yang harus ada dalam setiap pembelajaran.

Menurut penulis untuk dapat melaksanakan proses belajar yang efektif maka komponenkomponen berikut harus ada secara langsung ketika belajar mengajar dilaksanakan. Pertama, siswa,. Kedua, tujuan,. Ketiga kondisi,. Keempat., sumber-sumber belajar. kelima, hasil belajar. Kelima komponen tersebut harus berhubungan dan terlibat dalam komunikasi dialektik pada ruang dan waktu yang sama secara langsung.

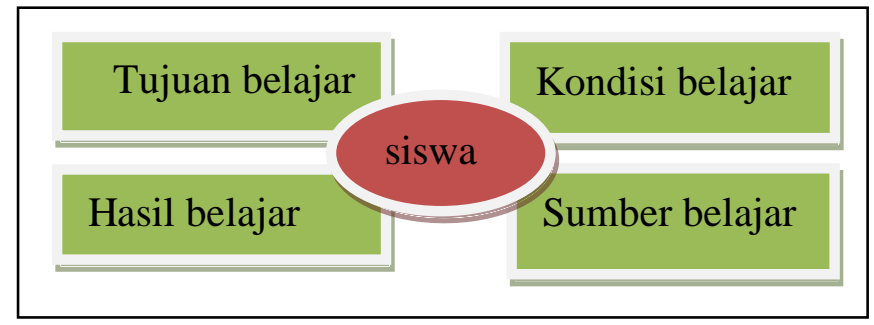

Proses belajar dengan tatap muka adalah proses belajar yang paling efektif dibandingkan dengan belajar dengan jaringan bila kembali kepada komponen kondisi. Kondisis adalah pengalaman belajar yang dialami langsung oleh para siswa dalam rangka mencapai tujuan khusus yang telah dirancang. Karena belajar dengan tatap muka melibatkan semua komponen sistem dalam pembelajaran. Situasi belajar seperti ini akan terasa tetap hidup karena guru dapat memantau secara langsung segala aktivitas yang berlangsung selama belajar. Berdasar pada pengalaman mengajar dan belajar yang dilakukan oleh para guru dan dosen serta para siswa dan mahasiswa mereka lebih memilih belajar dengan tatap muka dibandingkan dengan belajar online. Ada beberapa alasan yang mendasari hal tersebut diantaranya adalah:

a. Belajar langsung lebih terkontrol dibanding belajar online sehingga siswa tetap fokus.

b. Materi materi pembelajaran yang tingkat kesulitannya lebih tinggi membutuhkan penjelasan langsung, tidak bisa dengan online yang sering terjadi gangguan komunikasi.

c. Melakukan tanya jawab dan diskusi secara langsung lebih masuk dibandingkan dengan diskusi jarak jauh

d. Mengorganisasikan kelas dengan cara belajar tatap muka tentu akan lebih mudah dibandingkan dengan belajar online.

\section{B. Kognitifisme dan Proses Belajar}

Dalam psikologi kognitif belajar lebih menekankan pada proses internal dari mental manusia. Dalam persepektif kognitif belajar itu adalah pristiwa mental bukan behavioral. Belajar adalah kegiatan yang berproses. Dalam proses itu akan terdapat berbagai tahapan perubahan prilaku kognitif, afektif dan psikomotorik dalam diri para siswa. Karena belajar itu adalah proses maka sudah tentu di dalamnya terjadi perubahanperubahan yang bertahap. Perubahan-perubahan yang terjadi timbul melalui fase-fase yang satu dengan yang lainnya bertalian secara berurutan da fungsional.

Menurut Jerome S. Bruner, dalam proses belajar siswa mengalami tiga tahap perubahan ketika mereka mendapatkan materi belajar. 

a. Fase informasi (tahap penerimaan materi)
b. Fase transformasi (tahap pengubahan materi)
c. Fase evaluasi (tahap penilaian materi)

Pada fase informasi siswa akan mendapatkan berbagai keterangan tentang materi yang diajarkan. Informasi yang disamapaikan oleh guru ketika proses belajar berlangsung bisa berupa informasi baru atau bisa juga berupa informasi yang bersifat tambahan yang memperdalam berbagai informasi yang telah didapatkan sebelumya.

Selanjutnya pada fase transformasi para siswa melakukan analisa terhadap keterangan dan informasi untuk ditransformasikan menjadi bentuk yang abstrak atau konseptual. Informasi yang sudah berbentuk konsep pada giliranya nanti dapat difungsikan oleh para siswa menjadi pengetahuan yang lebih luas. Bagi para siswa pemula, fase ini akan dirasa mudah bila dilakukan bimbingan langsung dari guru yang memiliki kemampuan dalam mentransfer materi pelajaran.

Kemampuan mengevaluasi oleh siswa tentang pengetahuan yang telah didapatkan adalah bentuk terakhir dari proses belajar kognitif. Siswa harus dapat menilai dirinya, sejauh mana kemudian pengetahuan atau informasi yang telah ditransfer oleh guru telah dikuasai.

Sejalan dengan pendapat diatas Wittig dalam bukunya Psyichology of Learning mengemukakan bahwa proses belajar itu mengacu pada beberapa tahapan yang harus dilewati, yaitu:

1. Acquosition (tahap
pemerolehan/penerimaan informasi
2. Storage (tahap penyimpanan informasi)
3. Retrieval (tahap mendapatkan kembali
informasi)
Pada tahap pertama siswa yang melakuan pembelajaran mulai menerima berbagai informasi sebagai stimulus dan memberikan respon pada informasi-informasi tersebut. Setelah itu siswa akan mulai untuk memahami dan memunculkan prilaku baru. Pada situasi ini terjadi pula asimilasi antara pemahaman dengan perilaku baru dalam diri siswa. Acquisition adalah tahap dasar dalam belajar, bila pada tahap ini terjadi kegagalan maka dapat berakibat gagal juga pada tahap selanjutnya.

Pada tahap storage siswa secara otomatis dapat melakukan proses pemahaman dan pemunculan terhadap prilaku baru setelah melewati proses acquisation. Pada situasi ini tentu melibatkan short term dan long term memori. Memori itu sendiri dapat diartikan sebagai proses mental yang meliputi pengkodean, penyimpanan, dan pemanggilan kembali informasi dan pengetahuan yang telah didapatkan.
Selanjutnya pada tahap retrieval atau recall siswa akan mengaktifkan semua sistem memorinya dalam rangka menghadapi pertanyaan pertanyaan yang diberikan untuk memberikan jawaban. Proses retrieval sesungguhnya adalah peristiwa mental dalam mengungkapkan kembali berbagai item-item yang telah disimpan di dalam memori berupa informasi, simbul, berbagai pemahaman, dan perilaku yang terbentuk sebagai respon atas stimulus yang dihadapi.

Untuk dapat belajar secara efektif dengan berbagai proses belajar dalam persepektif kognitif seperti yang diunkapkan diatas, maka belajar itu membutukan proses komunikasi langsung yang disertai dengan pembimbingan. Proses belajar jarak jauh seperti yang dilaksanakan pada situasi covid saat ini tidak bisa mendukung sepenuhnya proses penerimaan informasi dari guru kepada siswa. Belajar jarak jauh menafikan beberapa kepatutan dalam belajar, seperti kepatuhan, kedisiplinan dan penghormatan

Kepatuhan, kedisiplinan dan penghormatan kepada guru dalam belajar jarak jauh cukup terasa terabaikan. Proses belajar jarak jauh mengandalkan jaringan internet sebagai lokomotif utama. Ketika belajar sudah dimulai, tidak semua siswa kemudian akan bergabung secara bersamaan. Ada yang aktif sejak awal, ada yang aktif ditengah pembelajarn bahkan ada yang aktif ketika pembelajaran akan selesai. Selain itu terlihat juga tingkah dan laku yang diperlihatkan dalam proses belajar tidak mencerminkan prilaku belajar yang seharusnya. Ini yang menyebabkan tidak utuhnya informasi dan berbagai materi pelajaran yang disampaikan dapat dipahami oleh para siswa.

\section{Kognitif Sosial dalam Belajar}

Belajar sebaiknya dilakukan secara langsung pada satu tempat antara guru dan para siswa. Belajar secara langsung seperti ini akan menciptakan komunikasi timbal balik yang dapat saling memengaruhi satu dengan yang laiannya. Belajar secara langsung memainkan peran peran sosial. Dengan adanya peran sosial yang muncul, baik dari siswa, guru dan limgkungan akan menciptakan pengalaman, pengetahun dan keterampilan dalam diri siswa. Menurut Bandura belajar itu terjadi karena adanya kausalitas timbal balik antara tiga sisi.

Gambar; 02

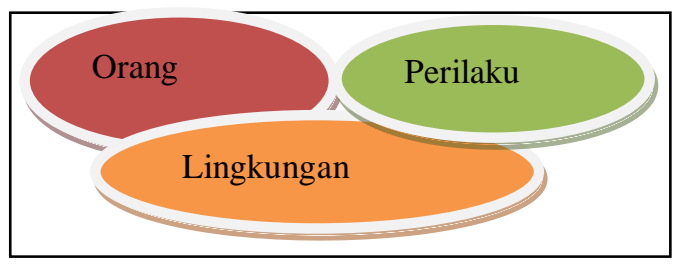


Pada gambar diatas mengimplikasikan bahwa pengaruh itu dapat datang dari berbagai sisi. Pada waktu tertentu satu faktor dapat lebih dominan dibanding faktor lain dan memengaruhi faktor lainnya. Dengan adanya proses saling mempengaruhi tersebut maka proses belajar dapat terjadi dengan baik.

Dalam teori kognitif sosial menjelaskan bahwa sebagian besar proses pembelajaran yang dilalui manusia terjadi pada lingkungan sosial. Proses belajar itu dapat dilakukan melalui mengamati orang lain. Dengan mengamati maka diperoleh pengetahuan, keterampilan, pengalaman dan keyakinan. Dalam pembelajaran sosial proses belajar terpengaruhi oleh intraksi timbal balik antar manusia (siswa), prilaku dan lingkungan.

Ketika guru memberikan sebuah pelajaran kepada siswa dikelas, maka siswa berfikir tentang apa yang dikatan oleh gurunya. Pada situasi ini maka kognisi siswa sedang dipengaruhi oleh lingkungan (faktor personal). Ketika siswa yang telah diberikan penjelasan tetapi tidak memahami penjelasan gurunya, lalu mengajukan sebuah pertanyaan, maka pada situasi ini dapat disebut bahwa perilaku memengaruhi lingkungan. Untuk memperkuat daya paham para siswa selanjutnya guru memberikan tugas pada siswa untuk diselesaikan. Pada situasi ini maka dapat disebutkan bahwa lingkungan memengaruhi kognisi, yang kemudian memengaruhi perilaku.

\section{Belajar dalam Perspektif Behavioristik}

Belajar adalah perubahan tingkah laku yang terjadi akibat adanya stimulus dan respon. Artinya bahwa siswa yang belajar akan memiliki kemampuan dalam memproduksi tingkah laku yang baru akibat dari hasil intraksi antara stimulus dan respon.

Agar proses belajar berjalan baik sesuai perspektif behaviorisme maka terdapat beberapa asumsi yang harus dipegang:

1. Sebagian besar perilaku orang diperoleh dari pengalaman karena rangsangan dari lingkungan.

2. Belajar merupakan hubungan berbagai peristiwa yang dapat diamati, yakni hubungan antara stimulus dan respon.

3. Belajar memerlukan suatau perubahan prilaku

4. Belajar paling mungkin terjadi ketika stimulus dan respon muncul dalam waktu berdekatan.

Dari berbagai ulasan diatas terlihat bahwa belajar secara langsung dengan tatap muka lebih memberikan hasil positif. Pembentukan perilaku baru dalam belajar dimungkinkan terjadi bila didukung oleh kondisi belajar yang hidup antara guru, siswa dan lingkungan. Guru dalam pembelajaran langsung tidak hanya bertugas untuk mentransfer pengetahuan, akan tetapi segala sikap dan tingkah guru selama belajar akan menjadi stimulus bagi para siswa. Lingkungan atau kondisi yang tercipta selama belajar juga dapat memunculkan respon prilaku dan kognisi dari siswa belajar.

\section{SIMPULAN DAN SARAN}

Setelah melakukan analisa terhadap data-data temuan dan mengulasnya menjadi pembahasan , maka sebagai akahir dari penelitian ini dapat disimpulkan sebagai berikut:

1. Penyebaran covid -19 sampai saat ini mengahruskan proses belajar dilakukan dari rumah sesuai dengan surat edaran mentri pendidikan.

2. Implementasi pembelajaran selama covid -19 yang diterapkan di Madrasah Aliah Attahzib kekait terbagi menjadi tiga fase. Fase belajar online, fase belajar tatap muka terbatas, dan fase belajar tatap muka normal.

3. Pembelajaran online dengan segala kelebihannya dianggap kurang efektif diterapkan di Madrasah Aliah Attahzib Kekait.

4. Adanya dukungan dari para wali santri dan ketua yayasan menjadi alasan dilakukannya pembelajaran tatap muka di Madrasah Aliah Attahzib.

5. Pembelajaran tatap muka dianggap lebih efektif dibandingkan non tatap muka seperti dalam perspektif kognitifisme dan behavioarisme.

\section{UCAPAN TERIMA KASIH}

Judul untuk ucapan terima kasih kepada lembaga atau orang yang sudah memberikan kontribusi selama penelitian dan referensi tidak diberi nomor.

\section{DAFTAR RUJUKAN}

Albert efandi Pohan, (2020). Konsep Pembelajaran Daring Berbasis Pendekatan Ilmiah, Jawa tengah:CV Saranu Untung.

Abdurrahmat Fathoni, (2006). Metodologi Penelitian \& Teknik Peyusunan Skripsi, Jakarta: PT Rineka Cipta.

Dale H. Schunk, (2012). Teori-teori pendidikan Persepektif Pendidikan, Yogyakarta:Pustaka Pelajar.

Muhibbin Syah, (2011) Psikologi Pendidikan dengan Pendekatan Baru, Bandung : Remaja Rosdakarya.

Molli hawyuni dan Nini Aryani, (2020) Teori Belajar dan Implikasinya dalam Pembelajaran, Edu Publisher:Jawa Barat. 
18 Ibtida'íy : Jurnal Prodi PGMI | Vol. 6, No. 2, Oktober 2021, hal. 10-18

Sri gusti dkk, (2020) Belajar Mandiri: Pembelajaran Daring di Tengah Covid-19, Yayasan kita menulis.

Mappanyompa, M. M., \& Mustapa Ali, M. A. M. A. (2017). Urgensi Penggunaan Multimedia Interaktif Terhadap Peningkatan Motivasi Belajar Siswa Dalam Pembelajaran Bahasa Arab Kelas Va Min Malang 2. Ibtida'iy: Jurnal Prodi PGMI, 2(2), 54.

Saifudin mahmud dan Muhammad Idham, (2017) Strategi Belajar Mengajar, Kualalumpur: shiah kuala university press.

Sugiyono, (2008) Metodologi Penelitian Kuantitatif Kualitatif dan $R \& D$, Bandung: Alfabeta.

Wina sanjaya, (2015) Perencanaan dan Desain sistem Pembelajaran, Jakarta : kencana.

Wina Sanjaya, (2010) Kurikulum dan Pembelajaran, Jakarta:Kencana.

https://nasional.kompas.com/read/2021/01/12/ 15253061/update-bertambah-10047-kasuscovid-19-indonesia-capai-846765?page=all

Abdurrahmat Fathoni, Metodologi Penelitian \& Teknik Peyusunan Skripsi, (Jakarta: PT Rineka Cipta, 2006), 37.

Sanafiah Faisal, penelitian kualitatif dasar-dasar dan aplikasi, (Malang: Bumi Anugarah, 1990), 53.

Abdurrahmat Fathoni, Metodologi Penelitian \& Teknik Peyusunan Skripsi..., 104.

Sugiyono, Metode Penelitian Kuantitatif Kualitatif dan $R \& D . . ., 147$.

Wina sanjaya, Perencanaan dan Desain sistem Pembelajaran, (Kencana: Jakarta, 2015), hal. 9

Muhibbin Syah, Psikologi Pendidikan dengan Pendekatan Baru, (Remaja Rosdakarya:Bandung), 2011, hal. 111

Dale H. Schunk, Teori-teori Pendidikan Persepektif Pendidikan, ( Pustaka Pelajar-Yogyakarta 2012), hal. 161

Molli hawyuni dan Nini Aryani, Teori Belajar dan Implikasinya dalam Pembelajaran, (Edu Publisher, 2020), hal. 1 